\title{
Międzynarodowe umowy kawowe Zarys prawnomiędzynarodowych ram światowego sektora kawy
}

\section{Uwagi wstępne}

W dniu 2 lutego 2011 roku weszła w życie Międzynarodowa umowa w sprawie kawy z roku 2007 (ang. International Coffee Agreement 2007), będąca siódmym $z$ rzędu międzynarodowym porozumieniem w kwestii szeroko zakreślonej współpracy na rzecz rozwoju światowego sektora kawy ${ }^{1}$. Umowa ta - podobnie jak jej sześć poprzedniczek - jest podstawą prawnoorganizacyjną stosunków łączących kilkadziesiąt międzynarodowych podmiotów (głównie państw), $\mathrm{w}$ ramach których podejmowane są działania na rzecz międzynarodowego rozwoju społeczno-gospodarczego w oparciu o kawę jako towar handlowy. Znaczenie tego systemu jest o tyle wyjątkowe, że kawa od wielu lat pozostaje w światowych stosunkach gospodarczych towarem o szczególnej randze, plasując się w ścisłej czołówce najbardziej wartościowych produktów międzynarodowego obrotu ${ }^{2}$. Celem niniejszego artykułu jest przybliżenie polskiemu czytelnikowi roli, jaką umowa ta odgrywa w międzynarodowym handlu kawą, a także syntetyczne zilustrowanie instytucji, które normuje.

1 Entry into force of the International Coffee Agreement 2007: 2 February 2011 - DN 95/11/ICA 2007 [ICO Document], 2.02.2011.

${ }^{2}$ R.H. Bates, Open-economy politics: the political economy of the world coffee trade, Princeton University Press 1997, s. 3. 
Międzynarodowa umowa w sprawie kawy została otwarta do podpisu 28 września 2007 roku w Londynie i była - jak już wspomniano - siódmą z kolei umową w tej materii. Pierwsza umowa podpisana została w roku $1962^{3}$ i weszła w życie rok później, stąd historia tych umów liczy sobie już pół wieku. Następne umowy wchodziły w życie kolejno w latach $1968^{4}, 1976^{5}, 1983^{6}, 1994^{7}$ i $2001^{8}$, zastępując jednocześnie umowy poprzednie. Sygnatariuszem umowy $z 2001$ roku była również po raz pierwszy $w$ historii Rzeczpospolita Polska9 ${ }^{9}$ jednakże obecnie obowiązującą umowę podpisała już tylko Unia Europejska, działając samodzielnie w ramach wyłącznych kompetencji w dziedzinie wspólnej polityki handlowej ${ }^{10}$. Umowa ta zawarta została na dziesięć lat, licząc od daty jej wejścia w życie.

Jednakże $z$ uwagi na to, że wiele postanowień powielane było w tekstach kolejnych umów (niektóre począwszy nawet od umowy pierwszej), nieodzowne będzie zachowanie w niniejszym artykule ujęcia wyraźnie historycznego. Obecnie obowiązująca umowa jest bowiem formalną kontynuacją sześciu poprzednich i jako taka przesądza o pewnej ciągłości poszczególnych ich regulacji. Stąd uprawnione jest posłużenie się terminem zbiorczym „umowy kawowe".

3 International Coffee Agreement 1962, United Nations Treaty Series, vol. 469, s. 169 .

4 International Coffee Agreement 1968, United Nations Treaty Series, vol. 647 , s. 3 .

5 International Coffee Agreement 1976, United Nations Treaty Series, vol. 1024 , s. 3.

6 International Coffee Agreement 1983, United Nations Treaty Series, vol. 1333 , s. 119 .

7 International Coffee Agreement 1994, United Nations Treaty Series, vol. 2086, s. 147.

8 International Coffee Agreement 2001, United Nations Treaty Series, vol. 2161 , s. 308.

9 Międzynarodowa Umowa w Sprawie Kawy z 2001 roku (Dz.U. z 2007 r. Nr 118, poz. 815).

10 Decyzja Rady 2008/579/EC 16 czerwca 2008 r. w sprawie podpisania i zawarcia w imieniu Wspólnoty Europejskiej Międzynarodowej umowy w sprawie kawy z 2007 r. (Dz.U. UE 2008, nr L 186, s. 12). 


\section{Geneza międzynarodowych umów kawowych}

Umowy kawowe należy zakwalifikować do kategorii umów surowcowych, które zawierane były pod auspicjami Konferencji Narodów Zjednoczonych ds. Handlu i Rozwoju od początku lat 60. XX wieku $^{11}$. Przyczyną ich zawierania były nasilające się perturbacje w zakresie podaży i cen pewnych strategicznych dla wielu gospodarek towarów. Pierwotnym celem tych umów była więc regulacja handlu międzynarodowego, która dokonywana miała być za pomocą interwencjonistycznych narzędzi polityki handlowej ${ }^{12}$.

Po raz pierwszy umowy surowcowe znalazły szersze ramy prawne w projekcie Karty Międzynarodowej Organizacji Handlu (Karty hawańskiej) z 1948 r. Kwestii tej poświęcony był cały rozdział Karty. Ustanawiał on przede wszystkim procedury, według których państwo członkowskie mogło zwołać konferencję w celu opracowania umowy surowcowej. Karta określała także warunki i zasady, które porozumienie takie powinno spełniać, wskazując na przykład, że powinny być one zaprojektowane w taki sposób, by cały czas zapewniać dostępność dostaw surowca adekwatną do światowego popytu, a także popyt ten zwiększać przez promowanie światowej konsumpcji określonych towarów. Karta zastrzegała również, że umowa surowcowa może być zawarta jedynie w przypadku stwierdzenia uciążliwych nadwyżek surowca lub powstania rozległego bezrobocia w sektorze związanym $z$ tym surowcem i tylko wtedy, kiedy interwencja państwa byłaby nieodzowna ${ }^{13}$. Ostatecznie Karta hawańska nigdy nie weszła w życie, jednak wiele zawartych w niej ustaleń posłużyło w następnych latach jako wzorzec regulacji kwestii surowców.

Problematyka obrotu surowcami nie została w większym stopniu uregulowana Układem Ogólnym w sprawie Taryf Celnych i Handlu

11 J.H. Jackson, W.J. Davey, A.O. Syke Jr., Legal Problems of International Economic Relations. Cases, Materials and Text. Third Edition, West Group 1995, s. 1176.

12 J. Białocerkiewicz, Powstanie i rozwój prawa międzynarodowego gospodarczego, Toruń 1987, s. 132; J. Gilas, Prawne problemy rynku międzynarodowego. Zarys problematyki prawa publicznego, Toruń 1975, s. 83.

13 J.H. Jackson, W.J. Davey, A.O. Syke Jr., op.cit., s. 1175. 
$(\text { GATT })^{14}$, co w zasadzie nie może dziwić, wziąwszy pod uwagę, że jednym $z$ jego priorytetowych zadań było zwiększenie wymiany dóbr, które to dokonać się miało przez liberalizację handlu międzynarodowego i przywrócenie warunków zbliżonych do wolnej konkuren$\mathrm{cji}^{15}$. Obok uzgodnienia obniżek ceł oraz szeregu zasad polityki handlowej Układ obejmował również ogólny zakaz stosowania pozataryfowych instrumentów polityki handlowej ${ }^{16}$. Co do zasady założenia Układu pozostawały więc $\mathrm{w}$ sprzeczności $\mathrm{z}$ istotą umów surowcowych, gdyż te prowadzić miały przecież do reglamentacji na rynku. $Z$ uwagi jednak na uczestnictwo w Układzie wielu państw rozwijających się, mimo wszystko zainteresowanych w protekcjonizmie rynków surowcowych stanowiących podstawę ich gospodarek, zdołano wypracować i tutaj pewne wyjątkowe uregulowania handlu surowcami. W rezultacie artykuł XX(h) Układu stanowił, że żadne jego postanowienia nie będą przeszkodą dla środków „podjętych w wykonaniu zobowiązań, wynikających z międzyrządowej umowy surowcowej, która jest zgodna $z$ kryteriami przedłożonymi układającym się stronom i nie została odrzucona”. Dodatkowo, jak stanowiło postanowienie uzupełniające art. XX(h) Układu zawarte w jego I załączniku, „wyjątek przewidziany w tym punkcie rozciąga się na wszelkie umowy surowcowe, które odpowiadają zasadom przyjętym przez Radę Gospodarczą i Społeczną w rezolucji nr 30(IV) z dnia 28 marca 1947 r." Rada ta na wniosek Organizacji NZ do spraw Wyżywienia i Rolnictwa ustanowiła Tymczasowy Komitet Koordynujący dla Międzynarodowych Uzgodnień Surowcowych (ang. Interim Coordinating Comittee for International Commodity Arrangements), który miał na celu ułatwienie międzyrządowych rozmów w omawianej materii. Jednocześnie Rada ustaliła we wspomnianej rezolucji, że zasady regulujące kontrolę umów surowcowych opracowane w Karcie hawańskiej będą traktowane jako ogólne wska-

14 General Agreement on Tarrifs and Trade, United Nations Treaty Series, vol. 55, s. 187.

15 W. Morawiecki, K. Michałowska-Gorywoda, Międzynarodowe organizacje gospodarcze, Warszawa 1985, s. 300.

16 M. Matsushita, T.J. Schoenbaum, P.C. Mavroidis, The World Trade Organization. Law, Practice and Policy, Oxford University Press 2003, s. 124 . 
zówki w tych rozmowach ${ }^{17}$. W ten sposób zasady wypracowane w Karcie hawańskiej mogły być wcielone w życie, pomimo iż sama Karta nigdy w życie nie weszła.

Na płaszczyźnie Układu Ogólnego nie doszło już do dalszych, konkretniejszych ustaleń w przedmiocie umów surowcowych. Przełomowe dla sprawy okazały się dopiero prace Konferencji Narodów Zjednoczonych ds. Handlu i Rozwoju. Rosnąca w wyniku procesu dekolonizacji liczba państw, a także żywsze zainteresowanie bloku socjalistycznego handlem międzynarodowym doprowadziły do podjęcia w połowie lat 50. rozmów na temat jego uregulowania i stworzenia powszechnej organizacji handlowej. Zaowocowały one podpisaniem Aktu Końcowego Konferencji ${ }^{18}$, w którym podkreślona została konieczność przyspieszenia wzrostu gospodarczego krajów słabiej rozwiniętych i standardu życiowego ich ludności ${ }^{19}$. Postanowienie art. 84 pkt 3 siódmego działu Aktu Końcowego Konferencji przewidziało podjęcie przez komisję surowcową lub ,jakikolwiek stały organ, który będzie ukonstytuowany w jej miejsce w ramach stałej struktury instytucjonalnej” negocjacji i badań dotyczących surowców i układów surowcowych ${ }^{20}$. Na forum Konferencji podjęto więc temat, który intencjonalnie starano się pomijać wcześniej w ramach Układu Ogólnego.

Szczególnym wydarzeniem dla problematyki surowców było zainicjowanie i rozwój Zintegrowanego Programu Surowcowego (ang. Integrated Programme for Commodities) na sesji w Nairobi w $1976 \mathrm{r}^{21}$ Rozwiązania Zintegrowanego Programu Surowcowego znacznie różniły się od tych przyjętych w systemie hawańskim. Jak już wspomniano, postanowienia systemu hawańskiego zakładały możliwość zawierania umów surowcowych jedynie w przypadkach uciążliwych nadwyżek surowców i ciężkiego bezrobocia w branży danego surowca. Uciążliwości musiały być tego stopnia, by nie można ich

17 UN Doc. E/437.

18 Final Act and Report of the United Nations Conference on Trade and Development, UN Publications, Sales No. 64.II.B. 11, s. 34.

19 W. Morawiecki, K. Michałowska-Gorywoda, op.cit., s. 307-308.

20 J. Makarczyk, Problematyka prawna Konferencji Narodów Zjednoczonych ds. Handlu i Rozwoju (UNCTAD), Studia Prawnicze 1970, z. 24, s. 26.

21 J. Białocerkiewicz, op.cit., s. 134. 
było usunąć przez działanie zwykłych sił rynkowych w odpowiednim czasie. Zintegrowany Program odszedł od tych założeń i został oparty na zasadach zadeklarowanych w Akcie Końcowym Konferencji. Przede wszystkim uzgodniono, że handel międzynarodowy jest jednym $z$ najważniejszych czynników w rozwoju gospodarczym, i przy tym uznano, że umowy surowcowe służą zabezpieczeniu ogólnej stabilności głównych rynków surowcowych. Stąd miały nie tylko za zadanie uporać się z nagłymi problemami na rynkach surowcowych, ale wręcz permanentnie je stabilizować, dbając o prawidłowy rozwój ekonomiczny i społeczny krajów producenckich.

W Programie zawarto listę surowców, w stosunku do których podejmowanie międzynarodowych środków w postaci porozumień surowcowych było konieczne. Określono także szeroki zakres wymogów, które porozumienia te muszą spełniać, uwzględniając przede wszystkim niezbędność zarządzania podażą oraz wprowadzając zinstytucjonalizowaną płaszczyznę dla negocjacji. Kryterium zastosowanym przez Program dla kwalifikacji surowców podlegających umowom był jedynie interes w eksportowaniu danego surowca po stronie rozwijających się gospodarczo krajów (of export interest to developing countries). Oczywiście każdy eksportowany przez państwo towar leży w kręgu zainteresowania tego państwa, dlatego pojęcie export interest interpretowano nieco wężej. Mianowicie chodzić tu musiało o towary (surowce), na których to głównie opierały się zarobki eksportowe państw, a handel nimi był szczególnie podatny na wszelkie zmiany na rynku światowym, mogące prowadzić do drastycznych spadków tych zarobków, tj. o towary będące kluczową pozycją eksportową 22 .

Umowy chronić więc miały gospodarki narodowe charakteryzujące się pogłębioną „monotowarowością”, stanowiącą główne zagrożenie ich ewentualnych załamañ ${ }^{23}$. Międzynarodowe porozumienia kawowe były odpowiedzią na postulat rozwiązania tego problemu w sektorze kawowym.

22 Wśród wyróżnionych przez Zintegrowany Program Surowcowy towarów oprócz kawy, o której mowa w niniejszym opracowaniu, wystąpiły ponadto banany, kakao, cukier, mięso, herbata, oleje roślinne, bawełna, kauczuk, drewno, a także różne minerały.

23 J. Białocerkiewicz, op.cit., s. 135. 


\section{Umowy kawowe jako narzędzie międzynarodowej polityki handlowej}

Międzynarodowa umowa kawowa $z$ roku 1962 stworzyła podstawy regulacji handlu kawą $\mathrm{w}$ oparciu o ograniczenia ilościowe w eksporcie (tzw. kwoty eksportowe), a także zapoczątkowała swoisty system, w którym centralną rolę odgrywa do dziś powołana tą umową Międzynarodowa Organizacja Kawy (ang. International Coffee Organization). W skład organizacji weszli wszyscy sygnatariusze umowy, tj. siedemdziesiąt jeden państw podzielonych na dwie kategorie członkowskie: członków eksportujących i członków importujących ${ }^{24}$. Kryterium klasyfikacji do danej grupy stał się bilans handlowy członków. Członkami eksportującymi zostawali więc ci sygnatariusze umowy, których wywóz kawy przekraczał przywóz (eksporterzy netto), z kolei członkami importującymi stawali się odpowiednio ci sygnatariusze, których przywóz kawy przekraczał wywóz (importerzy netto).

Ekonomiczne postanowienia dotyczące reguł nakładania kwot na eksportujących członków organizacji pojawiały się w tekstach następnych trzech umów. Kwestia regulacji cen postawiona była w tych umowach na pierwszym miejscu. Ich celem nadrzędnym była stabilizacja tych cen tak, aby były one słuszne (equitable prices), a więc utrzymane na poziomie co najmniej zadowalającym zarówno eksportujących, jak i importujących członków organizacji. Można powiedzieć więc, że w umowach tych, dla ukształtowania stosunków między krajami rozwiniętymi gospodarczo (czyli przede wszystkim importerami kawy), a krajami rozwijającymi się (eksporterami), obrano konstrukcję sprawiedliwości wyrównawczej. Opierała się ona na zasadzie kompensacji, dopuszczając chociażby stosowanie preferencji ${ }^{25}$.

Jak wskazano, proces stabilizacji cen odbywał się za pomocą kontroli podaży kawy na rynku światowym przez nałożenie na

24 B.S. Fisher, The International Coffee Agreement. A Study in Coffee Diplomacy, Praeger Publishers 1972, s. 41.

25 J. Gilas, Sprawiedliwość międzynarodowa gospodarcza, Toruń 1991, s. 17. 
państwa eksportujące limitów w eksporcie. Wprowadzenie kontyngentów prowadziło do zmniejszenia całkowitej podaży kawy na rynkach państw importujących, co prowadzić $z$ kolei miało do wzrostu cen kawy na tych rynkach ${ }^{26}$. Kwoty eksportowe przynosić więc miały znaczną korzyść eksporterom, jako że zyskiwali oni na wzroście cen eksportowanej kawy w porównaniu $\mathrm{z}$ ceną obowiązującą w warunkach wolnego handlu ${ }^{27}$.

W przypadku państw importujących nie można raczej mówić o korzyściach ekonomicznych. Podstawową korzyścią ekonomiczną osiąganą przy zawieraniu porozumień o ograniczeniach ilościowych po stronie państw, do których importowany jest dany towar, jest ochrona własnych producentów. Jednak w przypadku porozumień w sprawie międzynarodowego handlu kawą państwa importujące kawę (państwa zachodnioeuropejskie, USA, Kanada, Japonia), z uwagi na specyfikę surowca, który uprawiany jest wyłącznie w strefie równikowej, nie miały własnych plantacji, jako że warunki klimatyczne w nich panujące nie pozwalały na jej uprawę. W ekonomicznym interesie nie leżało też, co oczywiste, zwiększenie cen kawy wywołane ograniczeniem podaży. W związku z tym motywy, dla których państwa te przystąpiły do porozumienia, były raczej natury politycznej. Poprawa sytuacji gospodarczej państw eksportujących, czyli rozwijających się państw Ameryki Południowej, Afryki i Azji, mogła zapobiec komunistycznej penetracji tych rejonów świata, leżała więc w politycznym interesie państw ówczesnego zachodniego bloku ${ }^{28}$. Dobrowolne ograniczenia eksportu kawy miały więc prowadzić do osiągnięcia korzyści gospodarczych przede wszystkim po stronie członków eksportujących MOK, stąd właśnie wynikać miał ich kompensacyjny charakter.

26 O istocie ograniczeń ilościowych zob.: A. Kuś, Publicznoprawne pozataryfowe $i$ parataryfowe instrumenty reglamentacji obrotu towarowego z zagranica, Lublin 2006, s. 178; T. Rynarzewski, A. Zielińska-Głębocka, Międzynarodowe stosunki gospodarcze. Teoria wymiany i polityki handlu międzynarodowego, Warszawa 2006, s. 342-344.

27 T. Rynarzewski, A. Zielińska-Głębocka, op.cit., s. 342.

28 R.H. Bates, op.cit., s. 134. 
Mechanizm kwot eksportowych podlegał na przestrzeni ponad dwudziestu lat ich stosowania modyfikacjom, jednakże w zasadniczej postaci pozostawał w każdej kolejnej umowie podobny. Umowy wyznaczały państwom eksportującym tzw. kwoty bazowe, czyli początkowe wielkości dopuszczalnego eksportu kawy. Oddawały one wielkość produkcji kawy w danym kraju i co za tym idzie, potencjalną wielkość jego eksportu. Niemniej nie można powiedzieć, że były one wiernym odzwierciedleniem stanu faktycznego, jako że podlegały politycznej negocjacji między eksportującymi państwami stronami danej umowy, zainteresowanymi w uzyskaniu jak najwyższej kwoty bazowej29. Na podstawie kwot bazowych przydzielane były następnie roczne kwoty eksportowe, stanowiące wolumen dopuszczalnej ilości kawy zielonej, którą dane państwo mogło wyeksportować w ciągu roku kawowego (od 1 października do 30 września następnego roku). Roczne kwoty wynosiły jednakowy dla każdego państwa procent w stosunku do przyznanych umową kwot bazowych. Procent ten ustalała Międzynarodowa Rada Kawy, główny organ Międzynarodowej Organizacji Kawy, przy uwzględnieniu corocznych szacunkowych zapotrzebowań rynku ${ }^{30}$.

Oprócz kwot eksportowych ważnym instrumentem pomocniczym w pierwszych czterech umowach była także kontrola produkcji. Istotnym zagadnieniem przy okazji wprowadzenia kwot stał się bowiem problem wykorzystania uciążliwych zasobów kawy, które w wyniku ograniczenia eksportu nie mogły zostać przeznaczone do zagranicznego obrotu handlowego, a na które nie znalazł się również popyt na rynkach wewnętrznych. Powaga tego problemu znajdowała swój wyraz w samej preambule umowy z 1962 r., która zakładała, że można „spodziewać się tendencji ku [...] gromadzeniu uciążliwych zasobów [...], które mogą wyrządzać szkodę zarówno producentom, jak i konsumentom” (tłum. autor). Umowy stanowiły więc, że Międzynarodowa Rada Kawy powinna prowadzić politykę

29 Największe kwoty bazowe w każdej ze wskazanych umów uzyskiwały Brazylia i Kolumbia - do dziś najwięksi producenci kawy na świecie.

30 M. Raffaelli, Rise and demise of commodity agreements. An investigation into the breakdown of international commodity agreements, Woodhead Publishing Ltd, Cambridge 1995, s. 44. 
dotyczącą zasobów w ten sposób, by wykonać wytyczone przez nią cele produkcyjne, te zaś wyznaczane były przez Radę w drodze zalecenia dla każdego członka eksportującego $\mathrm{z}$ osobna i wskazywały wielkość produkcji pożądaną dla odpowiedniego zaspokojenia rodzimej konsumpcji, eksportu i ewentualnie potrzebnych zapasów. W rękach Rady spoczywało więc ustalenie wielkości podaży potrzebnej na światowym rynku i odpowiednie zalecenie członkom ograniczenia produkcji do wymiarów indywidualnie dla nich określonych. Wprowadzenie kontroli produkcji (tak by produkcja ta była dostosowana do aktualnych potrzeb rynku) miało być zatem rozwiązaniem problemu uciążliwych nadwyżek powstałych w wyniku nałożenia kwot eksportowych.

Przedstawiony powyżej mechanizm przetrwał w praktyce do końca lat 80. W końcu jednak górę wzięły partykularne interesy poszczególnych członków Międzynarodowej Organizacji Kawy. Rosnąca niezgoda co do kształtu repartycji kwot eksportowych doprowadziła do zawieszenia przez Radę obowiązywania systemu kontyngentów. Przyczyną kontrowersji w łonie organizacji był również proceder sprzedawania kawy przez państwa eksportujące do państw niebędących stroną obowiązującej w danym okresie umowy. Eksport do nich odbywał się na zasadach wolnorynkowych, co powodowało ogromne różnice cenowe w stosunku do cen, za jakie kupowali kawę importerzy z MOK. Rosnące sprzeczności w interesach zarówno na linii importerzy-producenci, jak i pomiędzy samymi producentami spowodowały w końcu odstąpienie od stosowania kwot eksportowych w praktyce organizacji. Przyczyną tego były też ogólne tendencje w międzynarodowych stosunkach gospodarczych. Na początku lat 90. Runda Urugwajska GATT przyniosła znaczną liberalizację handlu międzynarodowego w sektorze rolnym. W jej wyniku Wspólnota Europejska zobowiązała się zmniejszyć wymiar ceł importowych na nieprzetworzoną kawę zieloną z pięciu procent do zera. Kanada, Stany Zjednoczone i Japonia już wcześniej zniosły całkowicie cła na kawę. Liberalizacja światowego handlu postępowała, w związku z czym zabrakło w nim również miejsca dla ograniczeń ilościowych w handlu kawą. Umowa z roku 1994 nie zawierała już żadnych $z$ dominujących wcześniej postanowień ekonomicznych, pomimo że pierwsze cztery porozumienia oceniano 
nawet pomyślnie w zakresie działań na rzecz wzrostu cen i ich stabilizacji ${ }^{31}$.

Umowa z 1994 r. całkowicie zmieniła charakter porozumień kawowych, co mocno zauważalne było już w jej art. 1, zawierającym enumerację celów umowy. Mianowicie wśród celów artykuł ten nie przewidywał już na pierwszym miejscu konieczności osiągnięcia rozsądnej równowagi pomiędzy światowym popytem i podażą ani unikania nadmiernych wahań poziomu dostaw, zasobów i cen. W tym miejscu umowa z 1994 r. wskazała jako cel przewodni zapewnienie ściślejszej współpracy międzynarodowej w związku ze sprawami dotyczącymi kawy. Tym samym „współpraca” w sektorze kawowym zastąpiła jego „regulację”. Strony umowy dążyły więc od tej pory przede wszystkim do stworzenia forum dla międzyrządowych konsultacji, a osiągnięcie racjonalnej równowagi pomiędzy światową podażą a popytem miało być wynikiem przedsięwzięć podejmowanych w warunkach wolnego rynku. Taki właśnie charakter utrzymała też umowa z 2001 roku oraz najnowsza umowa z roku 2007. Pomimo odstąpienia od postanowień dotyczących nakładania kwot eksportowych umowy te zachowały jednak istotne znaczenie w międzynarodowym handlu kawą, w dalszym ciągu konstytuując prawnomiędzynarodową podstawę systemu opartego na dorobku kilkudziesięcioletniej działalności Międzynarodowej Organizacji Kawy.

\section{Międzynarodowa Organizacja Kawy jako instytucja nadzorująca wykonanie umowy}

Umowy kawowe w swym zasadniczym przedmiocie nie rodziły bezpośrednio praw i obowiązków w zakresie świadczeń gospodarczych, lecz organizowały bezpośrednio lub pośrednio gospodarcze współdziałanie stron. Sygnatariusze ich zobowiązywani byli do podjęcia wszelkich koniecznych kroków, które umożliwią im wypełnienie

31 Ch.L. Gilbert, International Commodity Control. Retrospect and Prospect, The World Bank International Economics Department. Commodity Policy and Analisys Unit, Washington 1995, s. 22. 
swoich zobowiązań wynikających z umowy, oraz do pełnej współpracy pomiędzy sobą dla zabezpieczenia osiągnięcia celów umowy. Nie inaczej rzecz ma się w obecnie obowiązującej umowie, która jak zauważono - jest formalną kontynuacją umów poprzednich (szczególnie umów z 1994 i 2001 r., pozbawionych regulacji dotyczących kwot eksportowych) i w istocie nie zawiera bardziej doniosłych nowości, a stanowi raczej wyraz dostosowania jej treści do zmieniających się na świecie warunków polityczno-gospodarczych.

Zgodnie $z$ art. 1 umowy z 2007 r. ma ona na celu wzmocnienie światowego sektora kawy oraz wspieranie jego zrównoważonej ekspansji w warunkach rynkowych $z$ korzyścią dla wszystkich uczestników tego sektora m.in. przez promowanie międzynarodowej współpracy oraz stworzenie forum konsultacji międzyrządowych w sprawach dotyczących kawy. Substratem tej współpracy pozostaje od półwiecza Międzynarodowa Organizacja Kawy, która najpełniej realizuje wspomniany cel umów kawowych. Oprócz funkcji zinstytucjonalizowanego forum dla konsultacji organizacja ta pełni również funkcję swoistego strażnika realizacji pozostałych celów umowy, o których mowa będzie później. Organizacja powołana została na mocy pierwszej umowy kawowej „dla właściwego wykonania postanowień umowy i nadzorowania jej sprawnego funkcjonowania” (art. 7 umowy z 1962 r.), natomiast obecnie obowiązująca umowa postanowieniem art. 6 działalność organizacji przedłuża „w celu stosowania postanowień tej umowy”.

Siedzibą Międzynarodowej Organizacji Kawy jest Londyn, a do jej głównych organów, obok wspomnianej już wcześniej Rady Kawy, należy Dyrektor Wykonawczy. W celu usprawnienia prac organizacji Międzynarodowa umowa w sprawie kawy z 2007 r. nie uwzględniła organu, który istniał pod rządami wszystkich dotychczasowych umów - Zarządu, który wcześniej niejednokrotnie niepotrzebnie dublował działania Rady. Dnia 28 maja 1969 r. Międzynarodowa Organizacja Kawy podpisała $z$ rządem Zjednoczonego Królestwa szczegółową umowę w sprawie siedziby ${ }^{32}$, której to podlegają do dziś

32 Headquarters Agreement between United Kingdom of Great Britain and North Ireland and International Coffee Organization, United Nations Treaty Series, vol. 1018, s. 405. 
status, przywileje i immunitety przysługujące MOK, jej Dyrektorowi Wykonawczemu, członkom personelu i ekspertom, a także przedstawicielom członków organizacji przebywającym na terytorium Zjednoczonego Królestwa jako państwa przyjmującego w związku $\mathrm{z}$ wykonywaniem swych funkcji.

Międzynarodowa Rada Kawy jest organem naczelnym organizacji. Grupuje ona reprezentantów wszystkich sygnatariuszy umowy kawowej. Zadaniem jej jest samodzielne stanowienie o polityce i działalności organizacji, a nade wszystko wykonywanie postanowień umowy. W tym celu umowa wyposaża ją we wszelkie uprawnienia konieczne do realizacji tych postanowień. Uprawnienia te zakładają przede wszystkim możliwość stanowienia przez Radę prawa wewnętrznego organizacji, tj. wszelkich zasad i regulaminów koniecznych do realizacji postanowień umowy, w tym w szczególności własnego regulaminu postępowania, a także regulaminu finansowego i pracowniczego organizacji. Oprócz ogólnej klauzuli nadającej Radzie przedstawione wyżej uprawnienia, których wykonywanie zależy od indywidualnych celów i środków przyjętych przez samą Radę, umowa bezpośrednio reguluje też pewne szczegółowe kompetencje Rady. Należą do nich m.in.: ustanawianie strategicznego planu działania w celu określenia kierunku prac organizacji, prowadzenie ewidencji i rejestrów potrzebnych do wykonywania powierzonych jej funkcji, możliwość kreacji wszelkich komisji lub grup roboczych, których utworzenie uzna za konieczne, ustalanie rozdziału głosów w jej łonie, tworzenie systemu cen wskaźnikowych i zapewnienie publikacji codziennej jednolitej ceny wskaźnikowej odzwierciedlającej rzeczywistą sytuację rynkową, rozstrzyganie sporów wynikłych przy wykonywaniu umowy między członkami organizacji, a także dokonywanie ustaleń w sprawie konsultacji i współpracy z innymi organizacjami międzyrządowymi, w tym głównie $z$ ONZ i jej wyspecjalizowanymi agencjami.

Rada wydaje na swoich posiedzeniach decyzje i zalecenia, a poza posiedzeniami także rezolucje, wymagające późniejszego potwierdzenia na sesji plenarnej. Ciekawie przedstawia się sama procedura podejmowania tych aktów. Co do zasady Rada dążyć ma do wydawania wszystkich decyzji i zaleceń w drodze konsensusu, jednakże w przypadku jego braku wydaje swoje akty tzw. rozdzieloną więk- 
szością głosów, wynoszącą co najmniej 70\% głosów. Rozdzielona większość oznacza głosowanie wymagające do podjęcia decyzji większości głosów oddanych przez obecnych i wykonujących prawo głosu członków eksportujących oraz większości głosów, liczonych odrębnie, oddanych przez obecnych i wykonujących prawo głosu członków importujących. Łączna liczba głosów dla każdej kategorii członków wynosi tysiąc. Rozdzielane są one przez Radę na rok spośród członków danej kategorii w następujący sposób: każdy członek ma pięć głosów podstawowych, pozostałe głosy członków rozdziela się proporcjonalnie do średniej wielkości ich odpowiednio wywozu bądź wwozu kawy w poprzednich czterech latach kalendarzowych (w zależności od kategorii członkostwa). Niemniej żaden z członków nie może mieć więcej niż $2 / 3$ głosów w swojej kategorii członkowskiej ${ }^{33}$.

Drugim najważniejszym organem MOK jest Dyrektor Wykonawczy. Jest on organem administracyjnym organizacji powoływanym przez Radę Kawy na pięcioletnią kadencję. Jego zadaniem jest więc obsługa techniczno-administracyjna organizacji, którą wykonuje za pomocą swojego personelu. Odpowiada on za wykonanie wszystkich obowiązków powierzonych mu przez Radę w związku z wykonaniem umowy. Może poddawać pod dyskusję Rady i innych organów wszelkie tematy, które uzna za konieczne dla prawidłowego wykonania umowy. Dyrektor przygotowuje okresowe analizy i sprawozdania w sprawie przestrzegania postanowień umowy, które następnie przedkłada Radzie pod rozwagę, a także może przedkładać Radzie propozycje projektów rozwojowych realizowanych ze środków m.in. Wspólnego Funduszu Towarowego. Ponadto w przypadku kontrowersji między członkami organizacji Dyrektor aktywnie uczestniczy w konsultacjach pomiędzy nimi, powołując niezależny komitet w celu pogodzenia stron. Z kolei na zewnątrz Międzynarodowej Organizacji Kawy Dyrektor występuje jako jej prawny reprezentant, w związku z czym ma prawo zawierać w imie-

33 W taki sposób do państw o największej liczbie głosów w Radzie tradycyjnie należą: wśród eksporterów kolejno: Brazylia, Wietnam i Kolumbia, a po stronie importerów: Unia Europejska (dysponująca głosami swoich członków) i Stany Zjednoczone. 
niu organizacji umowy z państwami członkowskimi, państwami trzecimi, a także $z$ innymi organizacjami międzynarodowymi.

\section{Stosunki organizacji z sektorem prywatnym}

Obok promowania międzynarodowej współpracy i tworzenia forum międzyrządowych konsultacji oraz negocjacji w sprawach dotyczących kawy równie istotnym zadaniem umowy jest stworzenie forum konsultacji $z$ sektorem prywatnym. Odpowiednie postanowienie $\mathrm{w}$ tej kwestii wyeksponowane zostało dopiero w umowie $\mathrm{z} 2001 \mathrm{r}$., natomiast w umowie z 2007 r. znalazło swoje miejsce w art. 1 pkt 2 . Zaakcentowanie tego środka do wzmocnienia światowego sektora kawy należy uznać za naturalną reakcję na zmianę charakteru porozumień, a także generalnych przekształceń w międzynarodowym handlu. Zachodzące w szybkim tempie procesy globalizacyjne spowodowały znaczne zmiany w podmiotowej strukturze światowego handlu, dając szczególne możliwości rozwoju potężnych koncernów transnarodowych. Współcześnie dochody niektórych z nich przewyższają niekiedy nawet dochody kilku państw członkowskich Międzynarodowej Organizacji Kawy. Nie sposób więc byłoby w tych okolicznościach funkcjonować organizacji bez uwzględnienia - i to na poziomie międzynarodowym - dążeń i interesów sektora prywatnego.

Dla wykonania tego założenia powołany został więc w łonie Organizacji Kawy organ doradczy w postaci Rady Konsultacyjnej Sektora Prywatnego. Zadaniem jej jest przedstawianie zaleceń w sprawach będących przedmiotem wszelkich obrad Międzynarodowej Rady Kawy. Może ona również samodzielnie przedstawiać Radzie pod rozwagę wszelkie sprawy związane $z$ umową, w tym w szczególności sprawy dotyczące zwiększenia wartości i zakresu światowej konsumpcji kawy, jakości kawy, łańcucha podaży, bezpieczeństwa żywności i rozwoju zrównoważonego sektora kawowego ${ }^{34}$. Niewątpliwie więc powołanie tego organu jest odpowiedzią na potrzebę

34 Private Sector Consultative Board - Terms of reference - ICC 102-12 [ICO Document], 1.04.2009. 
zwiększenia dostępu do informacji na temat finansów i zarządzania ryzykiem w sektorze kawy. Wiedza ta uznana została przez strony umowy za niezwykle pomocną dla uniknięcia zakłóceń równowagi między produkcją a konsumpcją kawy, powodujących niekorzystne wahania cen (vide preambuła). Do najważniejszych członków Rady Konsultacyjnej należą obecnie Europejska Federacja Kawy ${ }^{35}$, Narodowe Stowarzyszenie Kawy Stanów Zjednoczonych ${ }^{36}$, Stowarzyszenie Kolumbijskich Eksporterów Kawy, Brazylijska Rada Eksporterów Kawy oraz Stowarzyszenie Indonezyjskich Eksporterów Kawy.

Szerzeniu współpracy na tym polu służy również zwoływana co kilka lat przez Radę Kawy Światowa Konferencja Kawy, w której biorą udział wspólnie członkowie MOK, przedstawiciele sektora prywatnego oraz inni zainteresowani uczestnicy, również ci z krajów niebędących sygnatariuszami umowy. Odbywa się ona zwyczajowo podczas posiedzenia Rady Kawy, a jej forma, tytuł i temat ustalane są w porozumieniu z Radą Konsultacyjną Sektora Prywatnego ${ }^{37}$. Rada zwołuje też forum konsultacyjne ds. finansów w sektorze kawy, które ma na celu ułatwić kontakt pomiędzy producentami a instytucjami finansowymi i w konsekwencji ułatwić przepływ pomocnych dla producentów informacji na temat dostępnych narzędzi i usług finansowych, w tym głównie kredytów. Zgodnie $z$ umową szczególnie uwzględnione mają być $\mathrm{w}$ pracach forum potrzeby małych i średnich producentów oraz społeczności lokalnych w regionach produkujących kawę, co ma się przyczynić do zmniejszenia ubóstwa i dochowania postulatu zrównoważonej ekspansji ekonomicznej.

35 Członkami Federacji są m.in. Kraft Foods UK Ltd, Luigi Lavazza S.p.A., Nestlé UK Ltd, Sara Lee, Tchibo GmbH.

36 Członkami Stowarzyszenia są m.in. Starbucks Coffee Company, Nestlé USA, Kraft Foods North America, Sara Lee Foodservice.

37 Dotychczas odbyły się trzy takie konferencje. Pierwsza w Londynie w 2001 roku skupiła ponad 450 przedstawicieli przemysłu kawowego. Druga konferencja odbyła się w 2005 roku w Brazylii, gromadząc już ponad 1200 delegatów $z$ całego świata. Ostatnia zaś odbyła się w lutym 2010 roku w Gwatemali. 


\section{Główne postanowienia o charakterze obligacyjnym umowy}

Wzmocnienie światowego sektora kawy oraz wspieranie jego zrównoważonej ekspansji w warunkach rynkowych dokonane ma być dzięki szeregowi środków, enumeratywnie wymienionych w art. 1 umowy. Na kilka $z$ nich uwaga została zwrócona wcześniej, przy okazji oglądu dorobku instytucjonalnego umów. Do środków pozostałych należą przede wszystkim: ułatwianie ekspansji i przejrzystości międzynarodowego handlu kawą, propagowanie znoszenia barier handlowych, promowanie rozwoju konsumpcji i rynków kawy, promowanie jakości kawy, opracowywanie i ocena projektów rozwojowych, gromadzenie, rozpowszechnianie i publikowanie informacji ekonomicznych i technicznych, danych statystycznych i opracowań, prowadzenie prac badawczo-rozwojowych, promowanie programów szkoleniowych i informacyjnych, a także ułatwianie dostępu do informacji na temat narzędzi i usług finansowych. Środki te znajdują swoją konkretyzację w wielu postanowieniach szczegółowych umowy, zawartych w jej rozdziałach IX, X oraz XII. Są to rozdziały poświęcone odpowiednio promocji i rozwojowi rynku, projektom realizowanym przez organizację oraz danym statystycznym, badaniom i analizom.

$Z$ powyższego wynika, że podstawowym założeniem umowy jest wspieranie przez sygnatariuszy rozwoju rynku kawowego. Rozwojowi temu ma służyć m.in. praca na rzecz zwiększenia światowej konsumpcji kawy oraz poprawy jej jakości. Te dwa sprzężone ze sobą czynniki bezpośrednio przyczynić się mają do wzrostu globalnego popytu na kawę tak po stronie tradycyjnych państw konsumenckich, tj. członków importujących MOK, jak i państw dotychczas kojarzonych głównie $z$ eksportem, których rynek wewnętrzny był niewielki. W efekcie działanie takie ma prowadzić do rozwoju zarówno wielkościowego, jak i jakościowego rynku.

Konieczność położenia szczególnego nacisku na konsumpcję i jakość pojawiała się we wszystkich poprzednich umowach kawowych, nawet wtedy, gdy ich głównym celem była regulacja ograniczeń ilościowych. W umowie z 2001 r. stypulacja art. 34 stanowiła, że członkowie uznają potrzebę promowania, wspierania i zwiększa- 
nia konsumpcji kawy i będą dążyli do wspierania działań podejmowanych w tych zakresie. W obecnej umowie postanowienie art. 25 zakłada, że członkowie uznają korzyści, jakie odnoszą z wysiłków na rzecz promowania konsumpcji, poprawy jakości produktów oraz rozwoju rynków kawy. W związku $z$ tym w ramach promocji i rozwoju rynków realizowane mogą być kampanie informacyjne, badania, działania na rzecz rozbudowy potencjału oraz analizy dotyczące produkcji i konsumpcji kawy.

Jednym $z$ ważniejszych efektów starań w tej dziedzinie było m.in. zatwierdzenie przez Radę Kawy, jeszcze pod rządami umowy z 2001 r., na 89. sesji w 2003 roku końcowego „Planu działania w celu zwiększenia konsumpcji kawy", skoncentrowanego na rozwijaniu rynku przez działania dostosowane do specyfiki danych obszarów geograficznych ${ }^{38}$. Działania te mają uwzględniać odmienne warunki gospodarcze i kulturowe panujące na rynkach krajów produkujących kawę, na wschodzących rynkach państw takich jak Rosja czy Chiny, a także na tradycyjnych rynkach wieloletnich członków Międzynarodowej Organizacji Kawy. Wśród nich można wyróżnić prowadzenie badań nad zdrowotnymi aspektami konsumpcji kawy, finansowanie kampanii medialnych na temat pozytywnego wpływu kawy na zdrowie i organizowanie festiwalów tematycznych.

Z kolei konkretyzacją założenia dotyczącego promowania jakości kawy były w umowach kawowych postanowienia, według których członkowie będą dążyli do zakazu sprzedaży i reklamy produktów pod nazwą kawa, jeśli produkty takie zawierają mniej niż odpowiednik 95\% kawy zielonej podstawowego surowca (art. 27 obowiązującej umowy). Za wyraz formalnego zastosowania się do tego wymogu można uznać Dyrektywę 1994/4/WE Parlamentu Europejskiego i Rady z dnia 22 lutego 1999 r. odnoszącą się do ekstraktów kawy i cykorii. Dyrektywa ta definiuje pojęcie ekstraktu kawy, a także określa, jakie substancje można dodawać w trakcie jego wytwarzania. Zgodnie $z$ nią ekstrakt kawy w proszku musi zawierać wagowo nie mnie niż 95\% suchej masy pochodzącej z kawy. Jedynie przy spełnieniu tych wymagań produkt taki może być sprzeda-

38 Action Plan to increase coffee consumption - PC 13/03 Rev. 2 [ICO Document], 18.09.2003. 
wany pod nazwą handlową wymienioną w załączniku tej dyrektywy. Stąd nazwy takie jak „ekstrakt kawy”, „ekstrakt kawy rozpuszczalnej”, „kawa rozpuszczalna” lub „kawa instant” wolno stosować wyłącznie do sprzedaży wyrobów, które podlegają dyrektywie 1994/4, a jednocześnie ich stosowanie jest obowiązkowe (tak orzekł TSVE w wyroku z dnia 15 lipca 2004 r. w sprawie C-239/02 między Douwe Egberts NV a FICS - World BVBA). Dyrektywa wyraźnie wypełnia więc $\mathrm{w}$ tym zakresie postanowienia przewidziane $\mathrm{w}$ porozumieniach kawowych.

Innym działaniem mającym na celu poprawę jakości kawy było przyjęcie przez Radę Kawy „Programu dla poprawy jakości kawy”, w którym ustalono minimalne standardy jakościowe dla eksportu kawy $^{39}$. Również znaczącym działaniem było opublikowanie przez Radę Konsultacyjną Sektora Prywatnego wspólnie z wieloma europejskimi stowarzyszeniami przetwórców kawy swoistego kodeksu postępowania, wprowadzającego reguły bezpiecznego obrotu kawą ${ }^{40}$. Kodeks ma na celu dostarczenie wszystkim uczestnikom łańcucha dostaw kawy (farmerów, producentów, przewoźników, handlowców, przetwórców i dostawców) podstawowych informacji o procedurach dla zminimalizowania ryzyka zniszczenia towaru. Wskazówki te należą do kanonu dobrych praktyk kupieckich (zwyczajów handlowych), w związku z czym są powszechnie przestrzegane przez prywatne podmioty zaangażowane w światowy handel kawą.

W bezpośrednim związku $z$ działaniami na rzecz promocji rynku kawy pozostają także postanowienia umowy dotyczące podejmowania działań służących zwalczaniu przeszkód w handlu i konsumpcji. Waga tej kwestii powodowała, że odpowiednie odnośnie do niej stypulacje znajdowały się we wszystkich dotychczasowych porozu-

39 Coffee Quality Imrovement Programme - Implementation - ICC Resolution No. 407/02 [ICO Documents], 1.02.2002. I tak według tego dokumentu członkowie eksportujący nie powinni eksportować kawy, która ma powyżej 86 ziaren ze skazą na 300-gramowej próbce kawy w przypadku kawy arabica oraz powyżej 150 ziaren ze skazą na 300 g próbki w przypadku kawy robusta. Podobnie nie powinno dochodzić do eksportu kawy, która ma wskaźnik wilgotności poniżej 8\% lub powyżej 12,5\%.

40 Code of Practice. Enhacement of coffee quality through prevention of mould formation - PSCB No. 36/02 [ICO Document], 23.08.2002. 
mieniach kawowych. Uwzględniając swój wspólny interes, członkowie zobowiązują się do poszukiwania środków i sposobów, dzięki którym możliwe będzie stopniowe ograniczanie, a w końcu, tam gdzie to możliwe, wyeliminowanie barier utrudniających zwiększenie wymiany handlowej i konsumpcji (art. 24 ust. 4 umowy z 2007 r.). Do barier tych umowa zalicza na pierwszym miejscu procedury przywozowe stosujące się do kawy, w tym taryfy preferencyjne i inne, kontyngenty, działania monopoli rządowych i urzędowych agencji skupu oraz inne przepisy administracyjne i praktyki handlowe. Dalej do barier tych zaliczają się również procedury wywozowe oraz inne wewnętrzne uwarunkowania w zakresie handlu oraz krajowe i regionalne przepisy prawne i administracyjne, które mogą wpływać na poziom konsumpcji. Biorąc pod uwagę okresowe analizy przeszkód w konsumpcji przygotowywane przez Dyrektora Wykonawczego, należałoby przyjąć, że największymi przeszkodami w konsumpcji są obecnie taryfy importowe i eksportowe (podatki, cła) oraz podatek od towarów i usług ${ }^{41}$. W importujących państwach MOK cło wwozowe na kawę zieloną wynosi 0\%, podczas gdy na kawę przetworzoną (paloną) cła wahają się już w granicach od 20\% (Japonia), przez 7,5\% (UE), do 0\% (USA). Co do podatku VAT od przetworzonej kawy, najwyższa stawka obowiązuje w Danii (25\%), a najniższa na Cyprze, Malcie, w Irlandii oraz w Wielkiej Brytanii $(0 \%)^{42}$.

Katalog przeszkód w konsumpcji nie jest jednakże zamknięty i za takowe należy uznać zgodnie $z$ umową wszelkie środki, które mogą w większym lub mniejszym stopniu szkodzić wzrostowi konsumpcji kawy. Do wewnętrznych uwarunkowań w zakresie handlu oraz krajowych i regionalnych przepisów prawnych i administracyjnych można wszak zaklasyfikować nieskończoną paletę aktów normatywnych, począwszy od przepisów dotyczących bezpieczeństwa

41 Obstacles to the consumption of coffee. Interim report prepared by the GATT Secretariat - EB 2546/85 (E) [ICO Document], 20.03.1985.

42 Obstacles to consumption - ICC 103-5 Rev. 1 [ICO Document], 30.09.2009. 
żywności po przepisy dotyczące etykietowania i reklamy środków spożywczych $^{43}$.

Promowaniu i zwiększaniu konsumpcji oraz jakości kawy służy również zarządzanie przez organizację projektami rozwojowymi. Międzynarodowa Organizacja Kawy analizuje i doradza, a także opracowuje i ocenia projekty korzystne dla światowej gospodarki kawą, pozyskując zarazem fundusze na te projekty, najczęściej od innych organizacji sponsorujących lub finansujących (art. 1 pkt 8 umowy). Środki finansowe na realizację przedkładanych Międzynarodowej Organizacji Kawy projektów pochodzą przede wszystkim ze Wspólnego Funduszu Towarowego, będącego autonomiczną międzyrządową instytucją finansową ustanowioną w ramach Narodów Zjednoczonych w celu wspierania rozwoju gospodarczego producentów surowców ${ }^{44}$. Międzynarodowa Organizacja Kawy jest powołana jako organ formalnie przedkładający projekty do Funduszu, a następnie je nadzorujący. Jako że najczęściej z Funduszu pokrywane jest nie więcej niż 50\% całkowitego kosztu projektu, zadaniem MOK jest także znalezienie podmiotu współfinansującego taki projekt. Propozycje projektów mogą być przedkładane przez członków organizacji oraz przez Dyrektora Wykonawczego, przy czym wnioskodawcy inni niż rządy członków organizacji (np. związki handlowców czy konsumentów kawy, organizacje pozarządowe, międzynarodowe organizacje, instytucje naukowe czy inne podmioty

43 Por. opinia Rzecznika Generalnego TSUE Leenderta A. Geelhoeda w sprawie C-239/02: „niniejsza sprawa dotyczy przepisów wspólnotowych w dziedzinie etykietowania i reklamy środków spożywczych, w szczególności kawy. Chodzi przede wszystkim o ustalenie czy przepisy wspólnotowe dotyczące obowiązkowego stosowania nazw, pod którymi produkt jest sprzedawany do wyrobów wyprodukowanych na bazie kawy wykluczają możliwość jednoczesnego stosowania nazw fantazyjnych. Należy również ustalić, czy ustawodawstwa krajowe, które zakazują odwoływania się, przy okazji etykietowania i reklamy środków spożywczych, do działania odchudzającego lub opinii lekarskich, mogą być uznane za zgodne z pierwotnym i wtórnym prawem wspólnotowym”.

44 Common Fund for Commodities. Basic information on the submission of applications to the Common Fund for Commodities for financial support for activities related to coffee - EB 3573/96 Rev. 4 [ICO Documents], 21.05.2003. 
zajmujące się kawą) powinni uzyskać autoryzację ze strony właściwego rządu państwa członkowskiego MOK, tak aby propozycja projektu została przedstawiona $\mathrm{w}$ drodze oficjalnej delegacji. $\mathrm{Na}$ mocy art. 28 ust. 4 umowy z 2007 r. ustanowiona została Komisja ds. Projektów, której zadaniem jest szczegółowe opracowywanie i ocena projektów.

Do tej pory ponad 32 projekty na łączną sumę 93 mln dolarów zostały zatwierdzone do realizacji i sfinansowane przez Fundusz ${ }^{45}$. Najdroższy kosztował ponad $18 \mathrm{mln}$ dolarów i dotyczył rozwoju rynku kawy we wschodniej i południowej Afryce (Tanzania, Uganda, Zimbabwe). Jego rezultatem było wprowadzenie w państwach regionu odpowiedniej legislacji regulującej kwestie bezpiecznego składowania kawy w ramach opracowanego przez Międzynarodową Organizację Kawy Systemu Kwitów Składowych (ang. Warehouse Receipt System). Dzięki niemu w znaczny sposób uproszczony została obrót towarem, gdyż kwity składowe stanowią tytuły własności składowanej kawy i są zbywalne.

\section{Działalność statystyczna i badawcza Międzynarodowej Organizacji Kawy}

Umiejscowiony w rozdziale XII umowy art. 32 stanowi, że Międzynarodowa Organizacja Kawy działa jako centrum gromadzenia, wymiany i publikacji danych statystycznych dotyczących światowej produkcji, cen, eksportu, importu, dystrybucji i konsumpcji kawy oraz specjalistycznych informacji na temat uprawy, przetwarzania i wykorzystania kawy. Zgodnie zaś $z$ art. 34 organizacja wspiera opracowywanie badań i analiz dotyczących ekonomiki produkcji i dystrybucji kawy, wpływu środków podejmowanych przez rządy w krajach będących producentami i konsumentami kawy na produkcję i konsumpcję kawy, strategii w zakresie zarządzania ryzykiem finansowym, aspektów związanych z równowagą sektora kawy, a także możliwości rozszerzenia konsumpcji kawy w zakresie jej

45 Coffee development projects. Progress report - EB 3959/09 Rev. 1 [ICO Document], 9.2009. 
tradycyjnych i ewentualnie nowych zastosowan. W celu zapewnienia właściwego funkcjonowania tych postanowień Rada może zobowiązać członków do dostarczania informacji uznanych przez nią za konieczne, a w razie ich niedostarczenia bądź napotkania trudności w dostarczeniu $\mathrm{w}$ racjonalnym czasie wszelkich wymaganych informacji może ona zobowiązać danego członka do wyjaśnienia powodów takiego niewywiązywania się z obowiązku, a nawet zastosować wobec niego sankcje organizacyjne.

Tylko od momentu wejścia w życie przedostatniej umowy na bazie tych postanowień organizacja przygotowała ponad trzydzieści ekonomicznych raportów z przeprowadzonych studiów i analiz. Ponadto objęła zasięgiem swoich badań wiele innych dziedzin zbieżnych w jakimś stopniu $\mathrm{z}$ realizacją celów umowy. Zaliczyć do nich można na przykład medycynę, ekologię czy agrobiologię w zakresie, w jakim ich przedmiotem jest kawa. Analiza rynków i stworzenie solidnej bazy danych stanowi znaczący kapitał Międzynarodowej Organizacji Kawy, dzięki któremu założenia ułatwienia ekspansji i przejrzystości międzynarodowego handlu kawą są faktycznie spełniane. Istotną rolę odgrywa przy tym codzienne publikowanie jednolitej ceny wskaźnikowej, tj. wzorca cenowego, będącego ogólnym punktem odniesienia dla cen kawy zielonej (nieprzetworzonej) dla wszystkich głównych rodzajów kawy, niezależnie od regionu pochodzenia. Dane dotyczące cen głównych gatunków kawy są zbierane i codziennie wysyłane do siedziby Międzynarodowej Organizacji Kawy przez agentów Dyrektora Wykonawczego działających na rynkach amerykańskim (Nowy Jork), niemieckim (Brema i Hamburg) i francuskim (Marsylia i Hawr). Następnie na podstawie specjalnych algorytmów oblicza się średnie ceny dla poszczególnych gatunków zielonej kawy (ceny wskaźnikowe), a na ich podstawie jednolitą cenę wskaźnikową, będącą fundamentalnym narzędziem dla oceny ekonomicznej sytuacji na rynku kawy ${ }^{46}$.

Ułatwieniu przejrzystości międzynarodowego handlu kawą służyć ma też system świadectw pochodzenia transportów kawy, regulo-

${ }^{46}$ Rules on statistics - Indicator proces. Procedures for collection, transmission, calculation and publication of group and composite prices effective from 1 October 2001 - EB 3776/01 Rev.1 [ICO Document], 28.03.2002. 
wany przez art. 33 umowy. Zgodnie $z$ nim w celu ułatwienia gromadzenia danych statystycznych na temat międzynarodowego handlu kawą, a także aby ustalić ilość kawy, która została wywieziona przez każdego członka eksportującego, organizacja stworzy system świadectw pochodzenia. W związku z tym każdy wywóz kawy przez członka eksportującego musi zostać objęty ważnym świadectwem pochodzenia, zawierającym takie informacje, jak: nazwa eksportera, kraj przeznaczenia, kraj przeładunku, nazwa przewoźnika, opis i waga kawy ${ }^{47}$. Oryginał świadectwa towarzyszy ładunkowi kawy w trakcie transportu, natomiast kopia wysyłana jest do siedziby Międzynarodowej Organizacji Kawy w celu dokonania audytu.

\section{Zakończenie}

Międzynarodowa umowa w sprawie kawy z 2007 r. obowiązywać ma przez dziesięć lat od daty wejścia w życie, z możliwością jej przedłużenia przez Radę Kawy na jeden bądź kilka okresów, nieprzekraczających łącznie ośmiu lat. Tak długi w stosunku do poprzednich umów okres obowiązywania świadczyć powinien o pewnym ugruntowaniu roli i charakteru umowy kawowej. $Z$ pewnością obok ważnych poprawek instytucjonalnych w Międzynarodowej Organizacji Kawy największym osiągnięciem umowy jest wzmocnienie uczestnictwa sektora prywatnego w pracach tej organizacji. Szczególnie ważne dla przyczynienia się do rozwoju ekonomicznie zdywersyfikowanego, globalnego sektora kawy, a także rozwoju społeczno-gospodarczego krajów producenckich powinno być bowiem ścisłe uwzględnienie w pracach organizacji strategii rynkowych kreowanych przez przedsiębiorców prywatnych. Najnowsza umowa w istotny sposób koreluje więc sferę publicznomiędzynarodową $z$ tą prywatną, dzięki czemu wysiłki podejmowane przez jej strony na rzecz realizacji wytyczonych celów nabierają cech

47 Rules on statistics - certificates of origin. Rules for the application of a system of certificates of origin effective from 1 October 2001 - EB 3775/01 [ICO Document], 23.05.2001. 
niezbędnej elastyczności. Jest więc ona ważnym instrumentem współpracy na rzecz międzynarodowego rozwoju, dostarczającym ram prawnych dla działalności Międzynarodowej Organizacji Kawy i podmiotów operujących w branży kawowej na poziomie międzynarodowym.

\section{SUMMARY}

\section{International coffee agreements}

The paper presents an outline of the legal frameworks created by the international coffee agreements for the global coffee industry from the early nineteen sixties. The paper explains the concept of the international coffee agreements, considers their origins and describes their content. The paper looks at the agreements in operation during two specific periods. The first covers the period from 1962 to 1994 . The agreements formed the legal basis for the trade and included export quotas in international coffee trade. The second period, from 1994 to date, is a time of profound change in the nature of the coffee agreements. In 1994, with the signing of the fifth agreement, export quotas gave way to liberalization, as seen in other international trade in accordance with the WTO. Currently, the main emphasis is cooperation with the private sector and to carry out development projects, particularly in the producing countries. The International Coffee Organization, based in London, was instituted to manage the objectives of each successive agreement. The paper includes a brief analysis of the structure of the organization.

Keywords: international coffee agreements, international law, international trade law, the International coffee Organization 